\title{
Evaluation of an alternative heterotopic transplantation model for ovarian tissue to test pharmaceuticals improvements for fertility restoration
}

\author{
Carmen Terren ${ }^{1}$, Jules Bindels ${ }^{1}$, Michelle Nisolle ${ }^{1,2}$, Agnès Noël $^{1}$ and Carine Munaut ${ }^{1 *}$
}

\begin{abstract}
Background: Ovarian tissue cryopreservation and transplantation (OTCTP) is currently the main option available to preserve fertility in prepubertal patients undergoing aggressive cancer therapy treatments. However, a major limitation of OTCTP is follicle loss after transplantation. The mouse is a model of choice for studying ovarian function and follicle development after ovarian tissue grafting in vivo. In these mouse models, ovarian tissue or ovaries can be transplanted to different sites. Our aim was to evaluate a new alternative to heterotopic transplantation models that could be useful to test pharmaceutical improvement for ovarian grafts after OTCTP.
\end{abstract}

Methods: Slow frozen murine whole ovaries were transplanted into the mouse ears (between the external ear skin layer and the cartilage). Ovarian transplants were recovered after 3, 14 or 21 days. Grafts were analyzed by immunohistochemistry and follicle density analyses were performed.

Results: An increase of ovarian vascularization (CD31 and Dextran-FITC positive staining), as well as cellular proliferation (Ki67 staining) were observed 3 weeks after transplantation in comparison to 3 days. Fibrosis density, evaluated after Van Gieson staining, decreased 3 weeks after transplantation. Furthermore, transplantation of cryopreserved ovaries into ovariectomized mice favored follicle activation compared to transplantation into non-ovariectomized mice.

Conclusion: The present study indicates that surgical tissue insertion in the highly vascularized murine ear is an effective model for ovarian grafting. This model could be helpful in research to test pharmaceutical strategies to improve the function and survival of cryopreserved and transplanted ovarian tissue.

Keywords: Ovarian tissue transplantation, Heterotopic transplantation, Animal model, Fertility restoration

\section{Background}

Cryopreservation of ovarian tissue followed by its autotransplantation is currently the main option to preserve the fertility of prepubertal patients or when oncological care is urgent $[1,2]$. However, this technique has certain

\footnotetext{
*Correspondence: c.munaut@uliege.be

${ }^{1}$ Laboratory of Tumor and Development Biology, GIGA-Cancer, University of Liège, Tour de Pathologie, Site Sart-Tilman, Building 23/4, Avenue Hippocrate, 13, 4000 Liege, Belgium

Full list of author information is available at the end of the article
}

limitations, including follicular loss immediately after grafting, possibly due to slow neovascularization, apoptosis $[3,4]$ and/or massive follicular recruitment, which is also known as follicular burnout [5]. Primordial follicle overactivation leads to a depletion of the ovarian reserve and thus to a reduced lifetime of the transplant [5]. Experimental in vivo models are of high value in this research field in order to test pharmacological strategies to limit transplantation-induced follicle loss and therefore to increase graft lifetime as well as the chances of original author(s) and the source, provide a link to the Creative Commons licence, and indicate if changes were made. The images or other third party material in this article are included in the article's Creative Commons licence, unless indicated otherwise in a credit line to the material. If material is not included in the article's Creative Commons licence and your intended use is not permitted by statutory regulation or exceeds the permitted use, you will need to obtain permission directly from the copyright holder. To view a copy of this licence, visit http://creativecommons.org/licenses/by/4.0/. The Creative Commons Public Domain Dedication waiver (http://creativeco mmons.org/publicdomain/zero/1.0/) applies to the data made available in this article, unless otherwise stated in a credit line to the data. 
pregnancies. In the literature, a number of transplantation sites have been investigated, including grafting intraperitoneally $[6,7]$, into the ovarian bursa $[8,9]$, under the kidney capsule $[10,11]$, intramuscularly [12] or subcutaneously $[13,14]$. A good transplantation site promotes fast revascularization of ovarian tissue, limiting the duration of ischemia and hence ovarian damage. The ovarian bursa is an interesting transplantation site as it is highly vascularized and natural pregnancies after murine ovarian transplantation are possible $[8,14,15]$. However, grafting beneath the murine ovarian bursa has several disadvantages compared to other sites. Indeed, only small tissue pieces can be inserted into the bursa via a small slit under microscopic control. In a recent study, the ovarian bursa site showed however the best ovarian tissue quality compared to subcutaneous graft sites [14]. This could be explained by the fact that in the subcutaneous site, the environment, pressure changes and temperature could influence ovarian quality. However, the subcutaneous graft site involves a simple surgical procedure and allows for external follow-up of follicular growth [16].

The intraperitoneal site may be an equivalent to the orthotopic graft site used in clinic [17]. Indeed, it provides a favorable environment for follicular development [16]. However, invasive surgery is necessary.

Our aim was to evaluate an alternative to heterotopic and/or other classical transplantation models for ovarian grafts through an adaptation of the "ear sponge assay" which was previously set up to study angiogenesis and lymphangiogenesis [20, 21]. This model involves ovarian tissue transplantation into the mice ear (between the skin layer and the cartilage). The first important advantage is to be less invasive than conventional models. Secondly, the transplantation site is highly vascularized. This feature is of high value in the case of ovarian grafts since a major follicle loss has been documented during the avascular ovarian transplantation [8, 18, 19, 22-24]. Finally, transplanted tissues remain easily accessible for subsequent therapeutic local treatments to limit follicle loss observed after transplantation of cryostored ovarian tissue.

We therefore evaluated this model by studying graft revascularization and survival after cryopreservation and transplantation.

\section{Materials and methods \\ Experimental design}

Mice were bred and maintained within the accredited Mouse Facility and Transgenics GIGA platform of the University of Liège (Belgium). The first experiment consists of the model validation. Therefore, slow frozen (SF) ovaries from SCID mice (6-10 weeks old) were transplanted ectopically into the ear of SCID mice
(12-14 weeks old, not ovariectomized) for either 3 days or 3 weeks $(n=4-5$ ovaries per group with one graft per mice). We also performed a comparison of follicle development of SF ovaries from BALB/c mice (7 weeks old) transplanted into ovariectomized or non-ovariectomized SCID mice (7-11 weeks old) with transplants recovery after 2 weeks $(n=11-12$ ovaries per group with one graft per mice). Transplanted ovaries from all experiments were fixed in $4 \%$ formaldehyde for histological assessment. The Animal Ethics Committee of the University of Liège approved this study (\#1934) and all experiments were performed in accordance with relevant guidelines and regulations.

\section{Ovariectomy, slow freezing (SF) and thawing procedure}

This procedure was previously described [25].

\section{Transplantation procedure}

Mice were anesthetized with ketamine hydrochloride (100 mg/kg body weight) and xylazine $(10 \mathrm{mg} / \mathrm{kg}$ body weight) by intra-peritoneal injection and a small horizontal incision was performed in the basal, external, and central parts of the ear and the external mouse ear skin layer was smoothly detached from the cartilage with thin forceps. The cryopreserved ovary (whole ovary) was introduced inside the hole, between the external mouse skin layer and the cartilage (Fig. 1). A suture point was made to close the skin incision.

\section{Histological assessment}

Intravenous injection of $200 \mu \mathrm{l}$ dextran-fluorescein isothio-cyanate (FITC, $2.5 \mathrm{mg} / \mathrm{ml}$ in PBS) was given to mice before sacrifice and then the skin of the ear was cut around the transplanted ovary. Ovaries fixed in $4 \%$ formaldehyde were paraffin-embedded and serially sectioned ( $5 \mu \mathrm{m}$ sections). The immunohistochemical detection of vascular endothelial cells (CD31) and functional blood vessels (dextran-FITC) was performed using specific primary antibodies (rabbit anti CD31 1/200 during $1 \mathrm{~h}$ (Abcam, Cambridge, UK) and anti-fluorescein-POD/ HRP during 30 min (Roche, Basel, Switzerland). Fibrosis and nucleus density were analyzed thanks to Van Gieson staining. Apoptosis and cell proliferation in the ovaries were evidenced by immunostaining of caspase-3 (1/300 overnight at $4{ }^{\circ} \mathrm{C}$, Cell Signaling, Danvers, USA) and Ki67 (1/100 during $1 \mathrm{~h}$, Abcam, Cambridge, UK), respectively.

Density of immunostaining was determined by computer-assisted image analysis as previously described [25]. For follicle quantification, hematoxylin and eosin sections were analyzed by light microscopy for the presence of primordial, primary and secondary or more mature follicles based on morphological classification of mouse follicles [26]. The follicular densities (number/ 


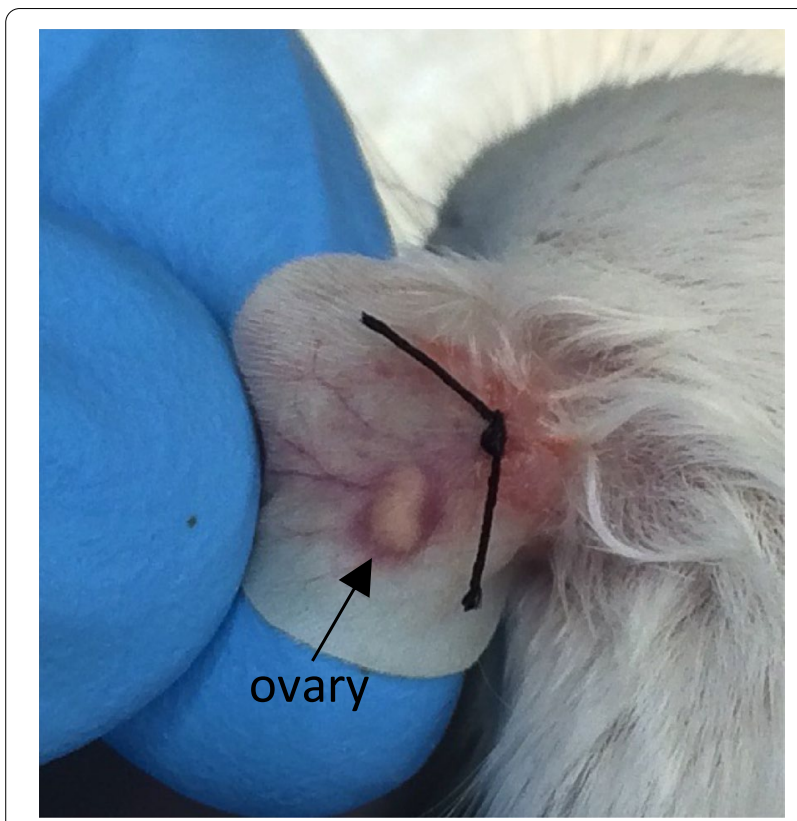

Fig. 1 Photograph of the place where ovaries were grafted. A horizontal incision was performed in the basal, external and central part of the mouse ear and the external mouse ear skin layer was smoothly detached from the cartilage with thin forceps. The ovary was introduced inside the hole, between the external mouse skin layer and the cartilage. A suture point was made to close the skin incision

$\mathrm{mm}^{2}$ ) were calculated after manually outlining the ovarian surface (NDP view software-NDP.view2 Viewing software U12388-01, Hamamatsu Photonics K.K., Japan).

\section{Statistics}

GraphPad Prism (GraphPad, San Diego, CA, USA) was used for statistical analyses. All data are presented as means \pm SEM. The Mann Whitney test was applied and $p$-value $<0.05$ was considered statistically significant.

\section{Results}

Grafts are revascularized 3 weeks after transplantation with an increased cell proliferation

A significant increase of vascular endothelial cells (CD31 staining) and functional blood vessels (FITC staining) was observed after 3 weeks of transplantation compared to 3 days (Fig. 2A-B). No modulation in apoptosis (Fig. 2C) was observed. Cell proliferation, as detected by the Ki67 staining quantification was increased after 3 weeks (Fig. 2D). Furthermore, a decrease in fibrosis density was observed after 3 weeks of transplantation compared to 3 days (Fig. 2E) but no modulation in nuclear density was observed (Fig. 2E).
Follicle activation is more pronounced after ovarian transplantation into ovariectomized compared to non-ovariectomized mice

A significant increase of secondary or more mature follicles was observed in ovaries transplanted into ovariectomized mice accompanied with a decrease in primary follicle density compared to non-ovariectomized mice. However, primordial follicle density was similar between the two experimental groups (Fig. $3 \mathrm{~A}-\mathrm{C}$ ).

\section{Discussion}

A number of different ovarian transplantation models exists (e.g., intraperitoneal, under the kidney capsule, into the ovarian bursa, subcutaneous, ...). Their main inconvenient is that they are all invasive, with the exception of subcutaneous transplantation sites [8, 9, 11, 16, 18, 19]. Our aim was therefore to develop a simpler and less invasive model, which is in addition easily accessible for local injections of different agents to improve graft health.

First, SF ovaries were transplanted into mice ears for 3 days or 3 weeks. An increase of ovarian vascularization was observed 3 weeks after transplantation compared to 3 days (CD31 and FITC staining). Indeed, hypoxic period was identified during the first 5 days after transplantation followed by gradual oxygenation of the ovarian transplant over the next 5 days [6]. Additionally, nuclear density and apoptosis remained stable through the transplantation time, indicating that cellular death is not increased 3 weeks after transplantation compared to 3 days. A decrease in fibrosis density was observed 3 weeks after transplantation compared to 3 days. However, an increase in fibrosis density was observed when marmoset, bovine or human ovarian tissue was transplanted subcutaneously into immunodeficient mice for 7 days compared to 3 days [19]. This observation determines an advantage of the ear transplantation site compared to the subcutaneous transplantation site.

On the other hand, Ki67 staining increased after 3 weeks of transplantation compared to 3 days. This could indicate follicle activation linked to transplantation. Altogether, these results indicate that this model could be usable as an alternative to invasive models.

In order to determine whether the mice own ovaries have an influence on the transplanted ovaries, a comparison of follicle development of ovaries transplanted into ovariectomized or non-ovariectomized mice has been performed. A significant increase of secondary or more mature follicles was observed in ovaries transplanted into ovariectomized mice accompanied with a decrease in primary follicle density compared to ovaries transplanted into non-ovariectomized mice. One of the likely explanations for the transplantation-induced 


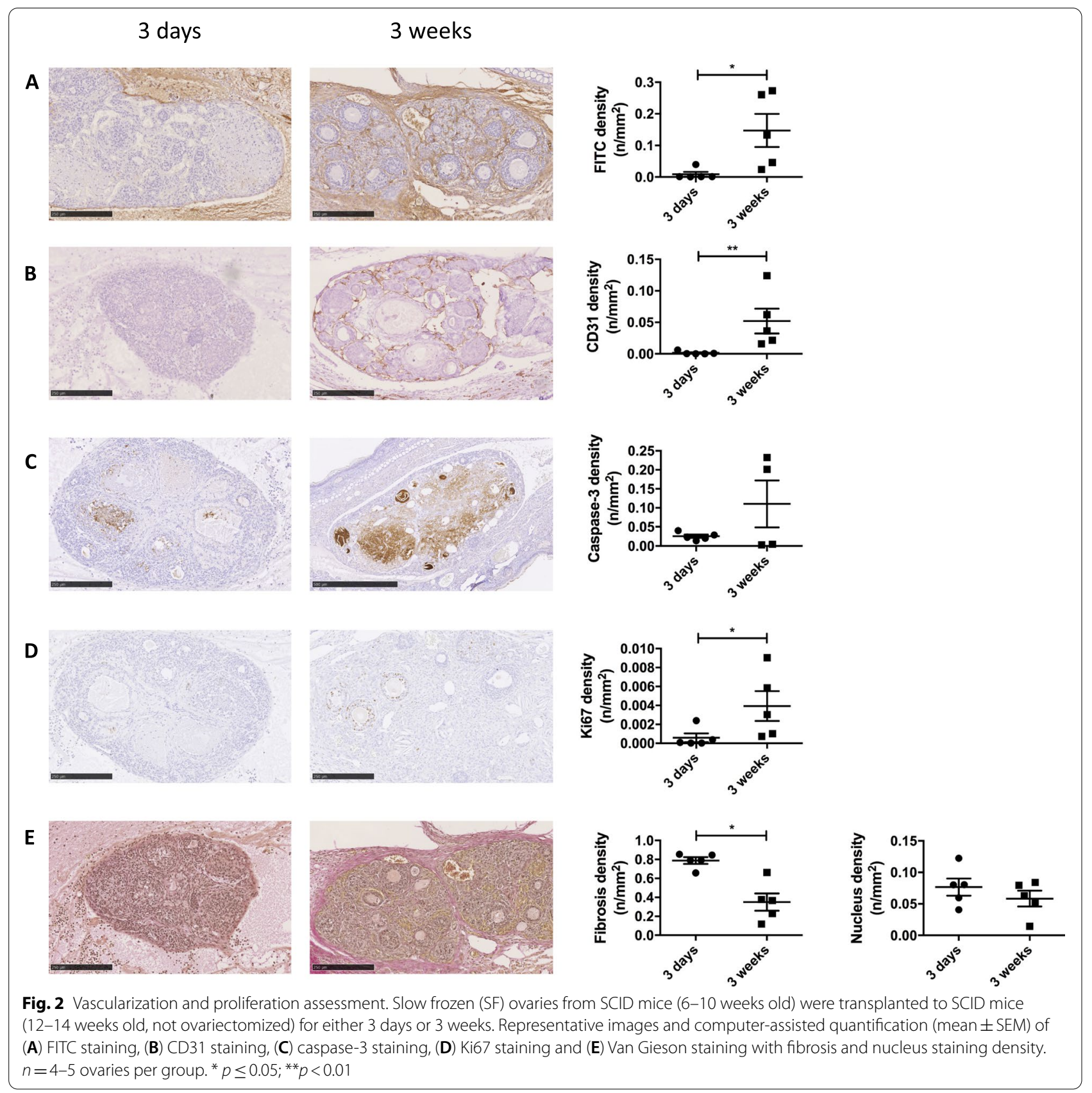

activation of primordial follicles in ovariectomized mice lies in the absence of the mice own ovaries. In normal physiology, growing follicles maintain the quiescence of primordial follicles via the production of inhibitory factors, such as antiMullerian hormone $(\mathrm{AMH})$ [20]. Furthermore, in a cryopreserved ovary, most of the mature follicles do not resist the cryopreservation process while primordial follicles, which have a low metabolic activity, are more tolerant to cryopreservation [21]. Therefore, in an ovariectomized mice, there is no AMH secretion (neither from the transplanted ovary nor from the removed mice own ovaries). An accelerate follicle activation was therefore observed. Indeed, the absence of growing follicles disrupts the balance between stimulatory and inhibitory factors in the graft, thereby leading to follicle activation $[5,19,27]$. In contrast, when the recipient mice are non-ovariectomized, the mice own ovaries are secreting $\mathrm{AMH}$, acting on the transplanted ovary to limit primordial follicle activation. 

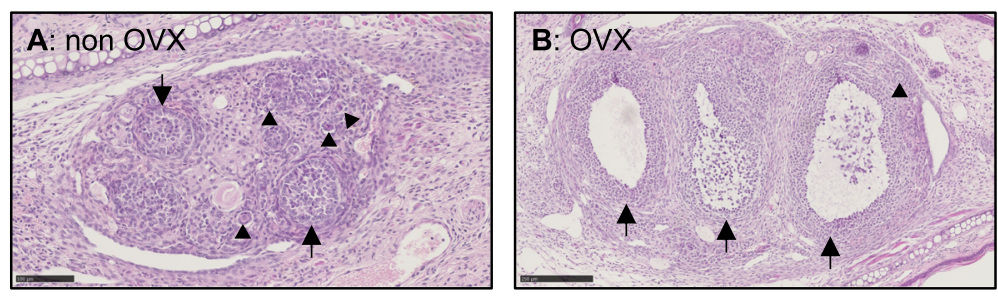

C

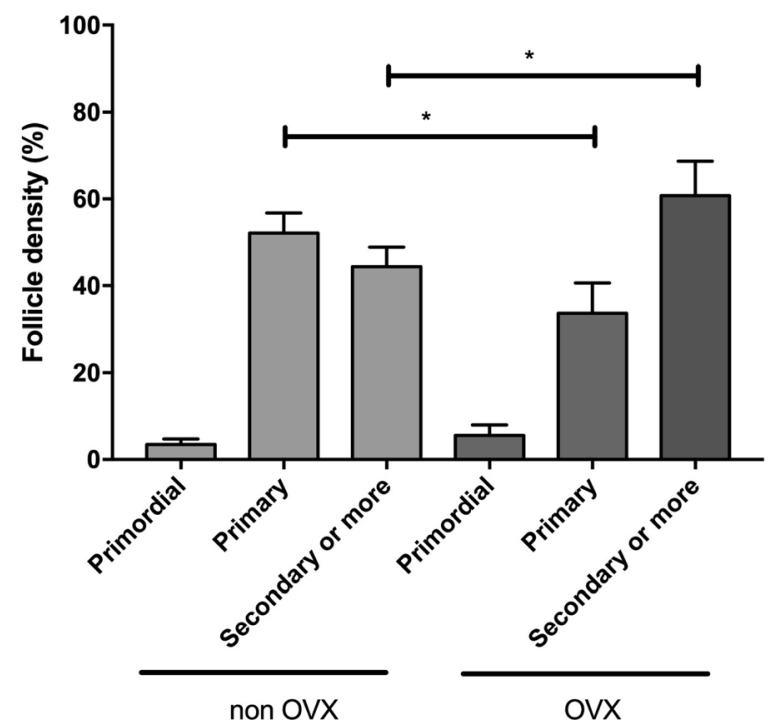

Fig. 3 Follicle development after transplantation into ovariectomized or non-ovariectomized mice. Transplantation of slow frozen (SF) ovaries from BALB/C mice (7 weeks old) into SCID mice (7-11 weeks old) for 2 weeks. Representative images of hematoxylin \& eosin staining of ovaries transplanted into a non-ovariectomized (A) and an ovariectomized (B) mice. Arrowheads show primary follicles and arrows show secondary or more mature follicles. (C) Follicle density of primordial, primary or secondary or more mature follicles (means \pm SEM). $n=11-12$ ovaries per group. * $p \leq 0.05$. OVX $=$ ovariectomy

\section{Conclusion}

In conclusion, the ear transplant model could be suitable for ovarian tissue transplantation due to the high revascularization rate. Furthermore, transplantation of cryopreserved ovaries into ovariectomized mice favors follicle activation as compared to transplantation into a non-ovariectomized mice. This new model is of particular interest for the testing of various pharmaceuticals strategies to limit follicle loss associated to the avascular ovarian auto-transplantation.

\section{Abbreviations}

OTCTP: Ovarian tissue cryopreservation and transplantation; FITC: Fluorescein isothio-cyanate; AMH: AntiMullerian hormone; SF: Slow freezing; OVX: Ovariectomy.

\section{Acknowledgements}

The authors acknowledge Isabelle Dasoul and Emilie Feyereisen for their excellent technical assistance. The authors also thank Silvia Blacher for statistical analysis.

\section{Authors' contributions}

C.T. performed the experimental work, prepared all figures and wrote the draft of the manuscript. A.N. conceived and designed the study. C.M. conceived, designed the study, interpreted data and wrote the manuscript. All authors read and approved the final manuscript.

\section{Funding}

This work was supported by grants from the Fonds de la Recherche Scientifique-FNRS (F.R.S.FNRS, Belgium), the Foundation against Cancer (foundation of public interest, Belgium), the Fonds spéciaux de la Recherche (University of Liège), the Centre Anticancéreux près I'Université de Liège, the Foundation Léon Fredericq (University of Liège).

\section{Availability of data and materials}

The data underlying this article will be shared on reasonable request to the corresponding author.

\section{Declarations}

\section{Ethics approval and consent to participate}

The Animal Ethics Committee of the University of Liège approved this study (\# 1934) and all experiments were performed in accordance with relevant guidelines and regulations. 


\section{Consent for publication \\ Not applicable}

\section{Competing interests}

The authors declare no competing interests.

\section{Author details}

'Laboratory of Tumor and Development Biology, GIGA-Cancer, University of Liège, Tour de Pathologie, Site Sart-Tilman, Building 23/4, Avenue Hippocrate, 13, 4000 Liege, Belgium. ${ }^{2}$ Department of Obstetrics and Gynecology, Hôpital de La Citadelle, University of Liège, B-4000 Liège, Belgium.

Received: 10 Auqust 2021 Accepted: 13 February 2022

Published online: 19 February 2022

\section{References}

1. Salama M, Isachenko V, Isachenko E, Rahimi G, Mallmann P. Updates in preserving reproductive potential of prepubertal girls with cancer: systematic review. Crit Rev Oncol Hematol. 2016;103:10-21. https://doi. org/10.1016/j.critrevonc.2016.04.002.

2. Angarita AM, Johnson CA, Fader AN, Christianson MS. Fertility preservation: a key survivorship issue for young women with cancer. Front Oncol. 2016;6:1-10. https://doi.org/10.3389/fonc.2016.00102/abstract.

3. Hancke K, Walker E, Strauch O, Göbel H, Hanjalic-Beck A, Denschlag D. Ovarian transplantation for fertility preservation in a sheep model: can follicle loss be prevented by antiapoptotic sphingosine-1-phosphate administration? Gynecol Endocrinol. 2009;25(12):839-43.

4. Baird DT. Long-term ovarian function in sheep after ovariectomy and transplantation of autografts stored at -196 C. Endocrinology. 1999;140(1):462-71. https://doi.org/10.1210/en.140.1.462.

5. Roness H, Gavish Z, Cohen Y, Meirow D. Ovarian follicle burnout: a universal phenomenon? Cell Cycle. 2013;12(20):3245-6.

6. Van Eyck AS, Jordan BF, Gallez B, Heilier JF, Van Langendonckt A, Donnez J. Electron paramagnetic resonance as a tool to evaluate human ovarian tissue reoxygenation after xenografting. Fertil Steril. 2009;92(1):374-81. Available from: http://www.linkinghub.elsevier.com/retrieve/pii/S0015 028208010650

7. Masciangelo R, Hossay C, Chiti MC, Manavella DD, Amorim CA, Donnez J, et al. Role of the PI3K and Hippo pathways in follicle activation after grafting of human ovarian tissue. J Assist Reprod Genet. 2019;10:6-13.

8. Dolmans MM, Martinez-Madrid B, Gadisseux E, Guiot Y, Yuan WY, Torre A, et al. Short-term transplantation of isolated human ovarian follicles and cortical tissue into nude mice. Reproduction. 2007;134(2):253-62.

9. Behringer R. Mouse ovary transplantation. Cold Spring Harb Protoc 2017;2017(3):pdb.prot094458. https://doi.org/10.1101/pdb.prot094458.

10. Lan C, Xiao W, Xiao-Hui D, Chun-Yan H, Hong-Ling Y. Tissue culture before transplantation of frozen-thawed human fetal ovarian tissue into immunodeficient mice. Fertil Steril. 2010;93(3):913-9. https://doi.org/10.1016/j. fertnstert.2008.10.020

11. Cheng Y, Kim J, Li XX, Hsueh AJ. Promotion of Ovarian Follicle Growth following mTOR Activation: Synergistic Effects of AKT Stimulators. Yan W, editor. PLoS One. 2015;10(2):e0117769. Available from: https://doi.org/10. 1371/journal.pone.0117769.

12. Soleimani R, Van Der Elst J, Heytens E, Van Den Broecke R, Gerris J, Dhont $M$, et al. Back muscle as a promising site for ovarian tissue transplantation, an animal model. Hum Reprod. 2008;23(3):619-26.

13. Ayuandari S, Winkler-Crepaz K, Paulitsch M, Wagner C, Zavadil C, Manzl C, et al. Follicular growth after xenotransplantation of cryopreserved/ thawed human ovarian tissue in SCID mice: dynamics and molecular aspects. J Assist Reprod Genet. 2016;33(12):1585-93. https://doi.org/10. 1007/s10815-016-0769-2.

14. Ruan X, Cui Y, Du J, Jin J, Gu M, Chen S, et al. Randomized study to prove the quality of human ovarian tissue cryopreservation by xenotransplantation into mice. J Ovarian Res. 2019;12(1):1-8.

15. Migishima F, Suzuki-Migishima R, Song S-Y, Kuramochi T, Azuma S, Nishijima M, et al. Successful cryopreservation of mouse ovaries by vitrification. Biol Reprod. 2003;68(3):881-7.

16. Dath C, Van Eyck AS, Dolmans MM, Romeu L, Delle Vigne L, Donnez J, et al. Xenotransplantation of human ovarian tissue to nude mice: comparison between four grafting sites. Hum Reprod. 2010;25(7):173443. https://doi.org/10.1093/humrep/deq131.

17. Donnez J, Dolmans M, Demylle D, Jadoul P, Pirard C, Squifflet J. Livebirth after orhotopic transplantation of cryopreserved ovarian tissue. Lancet. 2004;364(9443):1405-10.

18. Amorim CA, David A, Dolmans MM, Camboni A, Donnez J, Van Langendonckt A. Impact of freezing and thawing of human ovarian tissue on follicular growth after long-term xenotransplantation. J Assist Reprod Genet. 2011;28(12):1157-65.

19. Gavish Z, Spector I, Peer G, Schlatt S, Wistuba J, Roness H, et al. Follicle activation is a significant and immediate cause of follicle loss after ovarian tissue transplantation. J Assist Reprod Genet. 2018;35(1):61-9.

20. Garciá-Caballero M, Velde Van De M, Blacher S, Lambert V, Balsat C, Erpicum C, et al. Modeling pre-metastatic lymphvascular niche in the mouse ear sponge assay. Sci Rep. 2017;7(January):1-16. https://doi.org/10.1038/ srep41494.

21. Van de Velde M, García-Caballero M, Durré T, Kridelka F, Noël A. Ear sponge assay: a method to Investigate Angiogenesis and Lymphangiogenesis in Mice. In: Methods in Molecular Biology. 2018. p. 223-33. Available from: http://www.link.springer.com/. https://doi.org/10.1007/ 978-1-4939-7595-2_20

22. Silber SJ, DeRosa M, Goldsmith S, Fan Y, Castleman L, Melnick J. Cryopreservation and transplantation of ovarian tissue: results from one center in the USA. J Assist Reprod Genet. 2018;35(12):2205-13. https:// doi.org/10.1007/s10815-018-1315-1.

23. Greve T, Schmidt KT, Kristensen SG, Ernst E, Andersen CY. Evaluation of the ovarian reserve in women transplanted with frozen and thawed ovarian cortical tissue. Fertil Steril. 2012;97(6):1394-1398.e1. https://doi.org/10. 1016/j.fertnstert.2012.02.036.

24. Andersen ST, Pors SE, Poulsen L la C, Colmorn LB, Macklon KT, Ernst E, et al. Ovarian stimulation and assisted reproductive technology outcomes in women transplanted with cryopreserved ovarian tissue: a systematic review. Fertil Steril. 2019;112(5):908-21. Available from: https:// doi.org/10.1016/j.fertnstert.2019.07.008.

25. Terren C, Fransolet M, Ancion M, Nisolle M, Munaut C. Slow freezing versus vitrification of mouse ovaries: from ex vivo analyses to successful pregnancies after auto-transplantation. Sci Rep. 2019;9(1):19668. Available from: http://www.nature.com/articles/s41598-019-56182-8.

26. Myers M, Britt KL, Wreford NGM, Ebling FJP, Kerr JB. Methods for quantifying follicular numbers within the mouse ovary. Reproduction. 2004;127(5):569-80.

27. Visser JA, de Jong FH, Laven JSE, Themmen APN. Anti-Müllerian hormone: A new marker for ovarian function. Reproduction. 2006;131(1):1-9.

\section{Publisher's Note}

Springer Nature remains neutral with regard to jurisdictional claims in published maps and institutional affiliations.

Ready to submit your research? Choose BMC and benefit from

- fast, convenient online submission

- thorough peer review by experienced researchers in your field

- rapid publication on acceptance

- support for research data, including large and complex data types

- gold Open Access which fosters wider collaboration and increased citations

- maximum visibility for your research: over $100 \mathrm{M}$ website views per year

At BMC, research is always in progress.

Learn more biomedcentral.com/submissions 